\title{
Prevalence of Antibodies to Neospora caninum and Sarcocystis neurona in Sera of Domestic Cats From Brazil
}

\author{
Author(s): J. P. Dubey, D. S. Lindsay, D. Hill, S. Romand, P. Thulliez, O. C H. Kwok, J. C R. Silva , \\ M. C. Oliveira-Camargo, and S. M. Gennari \\ Source: Journal of Parasitology, 88(6):1251-1252. 2002. \\ Published By: American Society of Parasitologists \\ DOI: http://dx.doi.org/10.1645/0022-3395(2002)088[1251:POATNC]2.0.CO;2 \\ URL: http://www.bioone.org/doi/full/10.1645/0022-3395\%282002\%29088\%5B1251\%3APOATNC \\ $\% 5 \mathrm{D} 2.0 . \mathrm{CO} \% 3 \mathrm{~B} 2$
}

BioOne (www.bioone.org) is a nonprofit, online aggregation of core research in the biological, ecological, and environmental sciences. BioOne provides a sustainable online platform for over 170 journals and books published by nonprofit societies, associations, museums, institutions, and presses.

Your use of this PDF, the BioOne Web site, and all posted and associated content indicates your acceptance of BioOne's Terms of Use, available at www.bioone.org/page/terms_of_use.

Usage of BioOne content is strictly limited to personal, educational, and non-commercial use. Commercial inquiries or rights and permissions requests should be directed to the individual publisher as copyright holder. 
American Society of Parasitology. J. P. Dubey, D. S. Lindsay, D. Hill, S. Romand, P. Thulliez, O. C H. Kwok, J. C R. Silva, M. C. Oliveira-Camargo, and S. M. Gennari (2002). "Prevalence of Antibodies to Neospora caninum and Sarcocystis neurona in Sera of Domestic Cats From Brazil," Journal of Parasitology, Vol. 88, No. 6, pp. 1251-1252. doi: http://

dx.doi.org/10.1645/0022-3395(2002)088[1251:POATNC]2.0.CO;2

RESEARCH NOTES

\title{
Prevalence of Antibodies to Neospora caninum and Sarcocystis neurona in Sera of Domestic Cats From Brazil
}

\begin{abstract}
J. P. Dubey, D. S. Lindsay ${ }^{\star}$, D. Hill, S. Romand†, P. Thulliez†, O. C. H. Kwok, J. C. R. Silvał, M. C. Oliveira-Camargo§, and S. M. Gennarif, Parasite Biology, Epidemiology and Systematics Laboratory, Animal and Natural Resources Institute, Agricultural Research Service, United States Department of Agriculture, Building 1001, Beltsville, Maryland 20705-2350. *Center for Molecular Medicine and Infectious Disease, Department of Biomedical Sciences and Pathobiology, Virginia-Maryland Regional College of Veterinary Medicine, Virginia Tech, 1410 Prices Fork Road, Blacksburg, Virginia 44061-1092. †Laboratoire de la Toxoplasmose, Institut de Puérculture, 26 Boulevard Brune, F75014, Paris, France. łDepartamento de Medicina Veterinária Preventiva e Saúde Animal, Faculdade de Medicina Veterinária e Zootecnia, Universidade de São Paulo, Av. Prof. Dr. Orlando Marques de Paiva, 87, Cidade Universitária, São Paulo, SP 05508-000, Brazil. §Centro de Controle de Zoonoses da Prefeitura Municipal de Sao Paulo, Rua Santa Eulália 86, São Paulo, SP, Brazil. e-mail: jdubey@anri.barc.usda.gov
\end{abstract}

ABSTRACT: Antibodies to Neospora caninum and Sarcocystis neurona were determined in serum samples of 502 domestic cats from Brazil using direct agglutination tests with the respective antigens. Antibodies to $S$. neurona were not found in 1:50 dilution of any serum in the $S$. neurona agglutination test, suggesting that domestic cats from São Paulo city were not exposed to $S$. neurona sporocysts from opossums. Antibodies to $N$. caninum were found in $60(11.9 \%)$ of 502 cats with titers of 1:40 in 36 cats, $1: 80$ in 18 cats, 1:160 in 5 cats, and 1:800 in 1 cat using the Neospora agglutination test (NAT). Antibodies to $N$. caninum were confirmed by Western blotting in the sera of 10 cats with NAT titers of 1:80 to 1:800; this finding suggests that at least 10 cats had $N$. caninum-specific antibodies confirmed by 2 tests. This is the first documentation of natural exposure of cats to $N$. caninum.

Cats (Felis domesticus) are considered hosts to 3 related apicomplexans, Toxoplasma gondii, Sarcocystis neurona, and Neospora caninum; all 3 protozoans have a wide host range (Dubey and Beattie, 1988; Dubey and Lindsay, 1996; Dubey et al., 2001). There are numerous sero-epidemiological studies documenting the essential role of cats in the life cycle of T. gondii (Dubey and Beattie, 1988). Recently, cats were found to be an intermediate host for S. neurona, which is an important cause of a neurological disease of horses (Dubey et al., 2000; Dubey et al., 2001; Turay et al., 2002). Although there is no documented clinical case of $N$. caninum infection and no information on the prevalence of the parasite in cats, they can be successfully infected with $N$. caninum in the laboratory (Dubey and Lindsay, 1989a, 1989b). The objective of the present study was to determine the prevalence of antibodies to $S$. neurona and $N$. caninum in sera of naturally infected domestic cats.

Sera were collected during 1993-2000 from 502 domestic cats $(F$. domesticus) from São Paulo and Guarulhos cities, São Paulo State, in Brazil (Silva et al., 2002). A total of 470 stray cats was captured by the Center for Zoonosis Control of São Paulo and Guarulhos. Thirty-two cats were from a breeder in São Paulo; 26 of the 32 were born in houses and 6 were stray.

Cats were physically or chemically restrained using ketamine and xylazine. Blood samples were collected from each animal, and sera were stored at $-20 \mathrm{C}$ until serologic analysis. Antibodies to $N$. caninum were determined by the $N$. caninum agglutination test (NAT) as described by Romand et al. (1998). Sera were initially screened at the Beltsville laboratory at 1:25 dilution by NAT. Sera with positive or doubtful results were shipped to the Paris laboratory, where sera were diluted to $1: 20,1: 40,1: 80,1: 160,1: 400$, and 1:800, and examined by NAT (Romand et al., 1998).

Western blots were performed on cat sera that were positive at greater than $1: 80$ by NAT. Four to $12 \%$ gradient Bis-Tris gels containing detergent-extracted NC-1 tachyzoite proteins were electrophoresed in 50$\mathrm{mM}$ MOPS-sodium dodecyl sufate running buffer. Electroblotting was carried out by transfer of proteins onto nylon blotting membranes. The membranes were saturated with $1 \%$ nonfat dry milk solution in Trisbuffered saline and incubated in 1:100 dilution of cat sera, followed by goat anti-cat antibodies conjugated to horseradish peroxidase. Bands were visualized using 4-CN substrate kit (Kirkegaard and Perry, Gaithersburg, Maryland). Pre- and postinfection sera (20 days postinoculation) from pregnant cat no. 1, inoculated subcutaneously with $2 \times 10^{6}$
$N$. caninum tachyzoites, were used as negative and positive controls (Dubey and Lindsay, 1989b).

Antibodies to $S$. neurona were determined by the $S$. neurona agglutination test (SAT) as described by Lindsay and Dubey (2001). The SAT was performed at 1:50 dilution at the Blacksburg laboratory (Lindsay and Dubey, 2001).

Antibodies to $S$. neurona were not found in 1:50 dilution of serum of any cat. This result was unexpected because cats fed $S$. neurona sporocysts developed high $(\geq 1: 4,000)$ antibody titers in SAT (Dubey et al., 2002), and SAT antibodies were found in 13\% of 310 feral cats from Ohio (Stanek et al., 2003). The cats in the present study were city cats and probably had little chance to be exposed to opossum feces infected with $S$. neurona sporocysts.

Antibodies to $N$. caninum were found in 104 cats with titers of 1:20 in 44 cats, $1: 40$ in 36 cats, $1: 80$ in 18 cats, $1: 160$ in 5 cats, and 1:800 in 1 cat. Western blot analysis of these cat sera revealed antibody binding to $N$. caninum proteins in sera from 10 animals whose NAT titer was at least 1:80 (Fig. 1).

Toxoplasma gondii antibody titers in modified agglutination tests (MATs; Silva et al., 2002) of the 24 cats with NAT titers of 1:80 or more were generally low. The MAT titers of 18 cats with NAT titers of $1: 80$ were $<1: 25$ in 9 cats, $1: 25$ in 4 cats, $1: 50$ in 4 cats, and 1:500 in 1 cat. The MAT titers of 5 cats with NAT titers of 1:160 were $<25$ in 2 cats, $1: 25$ in 2 cats, and 1:50 in 1 cat. The MAT titer of the cat

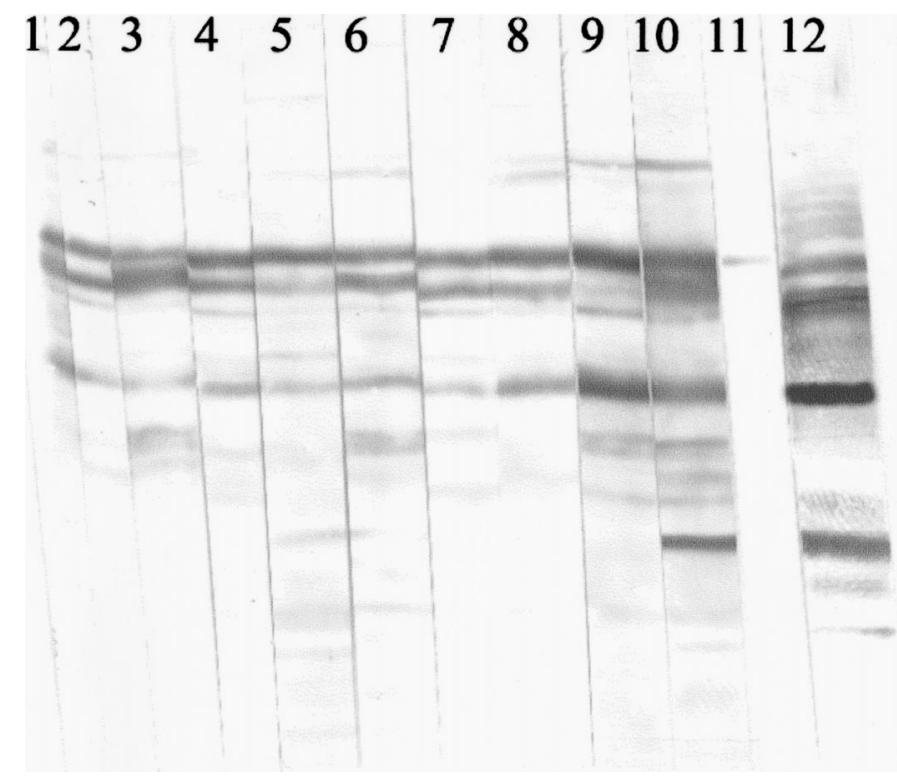

FIGURE 1. Western blot analysis of sera from 10 cats with antibody titers of 1:80 or higher in the NAT assay. Lanes 1-5, 1:80 NAT titer; Lanes 6-9, 1:160 titer; Lane 10, 1:800 titer; Lane 11, negative control cat sera; and Lane 12, positive control cat sera, 20 days postinfection with Neospora caninum tachyzoites. 
with the highest NAT was 1:50. Thus, 10 of 24 cats with NAT titers of 1:160 or more had no demonstrable $T$. gondii antibodies, suggesting no cross reactivity between NAT and MAT (Romand et al., 1998).

Finding a high titer to $N$. caninum in at least 10 of the cats is of interest because there is no published case of $N$. caninum infection in domestic cats. During the course of the discovery of $N$. caninum in 1988 , over 100 cats that died of $T$. gondii-like protozoan infection were examined, but $N$. caninum infection was not identified (Dubey and Carpenter, 1993; Dubey, unpubl.). However, experimentally infected cats can develop antibodies to $N$. caninum and clinical neosporosis (Dubey and Lindsay 1989a, 1989b; Dubey et al., 1990, 1996).

The NAT antibodies found in cats in the present study were not due to cross reactivity to $T$. gondii because antibodies to $T$. gondii were found in $26.3 \%$ of the same 502 cats tested in the $T$. gondii agglutination test (Silva et al., 2002).

Whether antibodies to $N$. caninum were due to past infection or cats had viable $N$. caninum infection is unknown because $N$. caninum has not yet been demonstrated in tissues of naturally infected cats. The NAT titer that should be considered specific for $N$. caninum infection in cats has not been determined. Therefore, all titers were given for cats. In cattle, even low titers (1:25) were considered indicative of exposure (Venturini et al., 1999), whereas Jenkins et al. (2000) considered the more conservative NAT titer of 1:80 as indicative of infection in cattle.

Cheadle et al. (1999) first reported $N$. caninum seropositivity in a small group of wild felids from Africa. They found low indirect fluorescent (1:50-1:200) antibody titers in 3 of 8 lions (Panthera leo) from Kruger National Park in South Africa and 1 of 16 cheetahs (Acinonyx jubatus) from Namibia.

\section{LITERATURE CITED}

Cheadle, M. A., J. A. Spencer, And B. L. Blackburn. 1999. Seroprevalences of Neospora caninum and Toxoplasma gondii in nondomestic felids from southern Africa. Journal of Zoo and Wildlife Medicine 30: 248-251.

Dubey, J. P., And C. P. Beattie. 1988. Toxoplasmosis of animals and man. CRC Press, Boca Raton, Florida, 220 p.

- AND D. S. LINDSAY. 1989a. Fatal Neospora caninum infection in kittens. Journal of Parasitology 75: 148-151.

, AND - 1989b. Transplacental Neospora caninum infection in cats. Journal of Parasitology 75: 765-771.

- AND - 1996. A review of Neospora caninum and neosporosis. Veterinary Parasitology 67: 1-59.

- , D. S. Adams, J. M. Gay, T. V. BAszler, B. L. BlaGBURN, AND P. ThUlliEz. 1996. Serologic responses of cattle and other animals infected with Neospora caninum. American Journal of Veterinary Research 57: 329-336. , AND T. P. LiPsCOMB. 1990. Neosporosis in cats. Vetrinary Pathology 27: 335-339.

, cats against Sarcocystis neurona infections. Veterinary Parasitolo$\mathrm{gy}$, in press.

- - - S. M. Reed, D. E. Granstrom, And C. A. SPEER. 2001. A review of Sarcocystis neurona and equine protozoal myeloencephatitis (EPM). Veterinary Parasitology 95: 89-131.

, W. J. A. Saville, D. S. Lindsay, R. W. Stitch, J. F. Stanek, C. A. Speer, B. M. Rosenthal, C. J. Nuoku, O. C. H. Kwok, S. K. Shen, And S. M. Reed. 2000. Completion of the life cycle of Sarcotystis neurona. Journal of Parasitology 86: 1276-1280

Jenkins, M. C., J. A. Caver, C. Buörkman, T. C. Anderson, S. RoMand, B. Vinyard, A. Uggla, P. Thulliez, And J. P. Dubey. 2000. Serological investigation of an outbreak of Neospora caninum-associated abortion in a dairy herd in southeastern United States. Veterinary Parasitology 94: 17-26.

LiNDSAY, D. S., AND J. P. DuBEy. 2001. Direct agglutination test for the detection of antibodies to Sarcocystis neurona in experimentally infected animals. Veterinary Parasitology 95: 179-186.

Romand, S., P. Thulliez, And J. P. Dubey. 1998. Direct agglutination test for serologic diagnosis of Neospora caninum infection. Parasitology Research 84: 50-53.

Silva, J. C. R., S. M. Gennari, A. M. A. Ragozo, V. R. Amajones, C. Magnabosco, L. E. O. Yai, J. S. Ferreira-Neto, and J. P. Dubey. 2002. Prevalence of Toxoplasma gondii antibodies in sera of domestic cats from Guarulhos and São Paulo, Brazil. Journal of Parasitology 88: 419-420.

Stanek, J. F., R. W. Stitch, J. P. Dubey, S. M. Reed, C. J. Nuoku, D. S. Lindsay, L. M. Schmall, G. K. Johnson, B. M. LaFave, and W. J. A. SAVILlE. 2003. Epidemiology of Sarcocystis neurona infections in domestic cats (Felis domesticus) and its association with equine protozoal myeloencephalitis (EPM). Veterinary Parasitology, in press.

Turay, H. O., B. C. Barr, A. Caldwell, K. R. Branson, M. K. R. Cockrell, AND A. E. MARsh. 2002. Sarcocystis neurona reacting antibodies in Missouri feral domestic cats (Felis domesticus) and their role as intermediate host. Parasitology Research 88: 38-43.

Venturini, M. C., L. Venturini, D. Bacigalupe, M. Machuca, I. Echaide, W. Basso, J. M. Unzaga, C. Di Lorenzo, A. GuglielMONE, M. C. Jenkins, AND J. P. DuBey. 1999. Neospora caninum infections in bovine foetuses and dairy cows with abortions in Argentina. International Journal for Parasitology 29: 1705-1708. 